\title{
Social innovation ecosystems, sustainability, and democratic experimentation: a study in Florianopolis, Brazil
}

\section{Carolina Andion 1}

\section{Graziela Dias Alperstedt 1}

Júlia Furlanetto Graeff 2

1 Universidade do Estado de Santa Catarina / Programa de Pós-Graduação em Administração, Florianópolis / SC - Brazil

2 Universidade do Estado de Santa Catarina / Núcleo de Inovações Sociais na Esfera Pública, Florianópolis / SC - Brazil

Cities have been conceived as one of the main loci for promoting changes in development patterns, and building solutions that can address the complexity of contemporary public problems. In this context, the study of social innovation ecosystems (SIE) and their effects on cities is a relevant theme, considering the socio-environmental crisis diversity and extent of the urban problems experienced. The research seeks to understand to what extent the SIE responds to problems experienced in the public arenas of the city. It proposes a pragmatist-inspired theoreticalmethodological approach to cartography and analysis of SIE that is being applied in the city of Florianópolis. Through the co-construction of a collaborative digital platform, the research observes actors, their interactions and practices, to understand "whether" and "how" this network favors "public inquiry" or democratic experimentation and/or promotes more sustainable development dynamics in the city.

Keywords: social innovation ecosystem; democratic experimentation; sustainability; city; pragmatism.

\section{Ecossistema de inovação social, sustentabilidade e experimentação democrática: um estudo em Florianópolis}

As cidades têm sido concebidas como um dos principais loci para promoção de mudanças nos padrões de desenvolvimento e na construção de soluções que possam fazer face à complexidade dos problemas públicos contemporâneos. Nesse contexto, o estudo dos ecossistemas de inovação social (EIS) e de seus efeitos nas cidades se coloca como temática relevante, considerando a crise socioambiental e diversidade e a amplitude dos problemas urbanos vivenciados. Trata-se de compreender em que medida os EIS geram consequências diante das problemáticas vividas nas arenas públicas da cidade. Eis o foco deste artigo, que propõe uma abordagem teórico-metodológica, de inspiração pragmatista, para cartografia e análise dos EIS, que se aplica na cidade de Florianópolis. Por meio da co-construção de uma plataforma digital colaborativa, observam-se atores, suas interações e suas práticas, com vistas a compreender "se" e "como" essa rede favorece a "investigação pública" ou a experimentação democrática e/ou promove dinâmicas de desenvolvimento mais sustentáveis na cidade.

Palavras-chave: ecossistema de inovação social; experimentação democrática; sustentabilidade; cidade; pragmatismo.

\section{Ecosistema de innovación social, sostenibilidad y experimentación democrática: un estudio en Florianópolis, Brasil}

Las ciudades han sido concebidas como uno de los principales loci para promover cambios en los estándares de desarrollo y construir soluciones que puedan enfrentar la complejidad de los problemas públicos contemporáneos. En este contexto, el estudio de los ecosistemas de innovación social (EIS) y sus efectos en las ciudades es un tema relevante, considerando la crisis socioambiental y la diversidad y magnitud de los problemas urbanos experimentados. Se trata de comprender en qué medida los EIS generan consecuencias frente a los problemas experimentados en los espacios públicos de la ciudad. Esta es el foco de este artículo, que propone un enfoque teórico-metodológico inspirado en el pragmatismo para la cartografía y el análisis de los EIS, que se aplica en la ciudad de Florianópolis. A través de la coconstrucción de una plataforma digital colaborativa, se observa a los actores, sus interacciones y sus prácticas, con el fin de comprender "si" y "cómo" esta red favorece la "investigación pública” o la experimentación democrática y/o promueve dinámicas de desarrollo más sostenibles en la ciudad. Palabras clave: ecosistema de innovación social; experimentación democrática; sostenibilidad; ciudad; pragmatismo. for Scientific and Technological Development (CNPq), and the Santa Catarina State University (UDESC) for the financial support given to this research. Also, the authors thank to the Brazilian Federal Agency for Coordination of Superior Level Staff Improvement (CAPES) for the Post-Doctoral Scholarship received from one of the authors to produce this research. Last but not least, the authors thank the entire team of researchers involved in the creation and implementation of the Observatory of Social Innovation of Florianopolis. 


\section{INTRODUCTION}

Cities have been built as one of the main loci for promoting changes in development patterns and building solutions to address the complexity of modern public problems. According to Wolfram and Frantzeskaki (2016, p. 12), a city can be considered a hybrid reality that:

\footnotetext{
interconnect various socio-technical systems (e.g., energy, water, buildings, transport). The mutually de-/stabilizing influences of such interconnected regimes have hardly been explored so far, but appear to be vital for guiding urban development towards sustainability. In addition, cities can equally be depicted as a set of coalescing SES that govern diverse resource stocks, flows and ecosystem services. Therefore, it becomes crucial to empirically explore how institutions, discourses, actor constellations and practices avoid or embrace this "hybrid" reality of cities as social-ecological-technological systems (SETS).
}

The demand for an adaptive co-management of local resources (Armitage et al., 2009) also emerges in the recent debate on sustainable territorial development (Lévesque, 2009; Vieira, Cazella, Cerdan, \& Carrière, 2010), and more particularly, in studies that discuss the relationship between cities and sustainability (Angelidou \& Psaltoglou, 2017; McPhearson, Andersson, Elmqvist, \& Frantzeskaki, 2015). These studies show the importance of "locating" the global debate, stressing that experiences of coping and governance of urban problems can generate conditions, resources, and opportunities for change, but also inertia and stagnation regarding the promotion of new development patterns.

These findings are connected to the field of public administration and specifically to public policy studies. There is an interest among scholars in this field to overcome the classic opposition between policy analysis and policy studies (Fischer \& Gottweis, 2013; Howlett, Ramesh, \& Perl, 2013; Shields, 2008). For them, it is a matter of broadening the debate to understand better the public action beyond the government. The intention is to comprehend new modes of public governance that can address the numerous and complex public problems that interrelate economic, social, cultural, and environmental dynamics, and, therefore, require intersectoral efforts (Osborne, 2006; Ostrom, 2010).

In this scenario, scientific studies that help to learn the limits and potential of new "democratic experimentation" (Ansell, 2012; Bohman, 2004) in the cities have gained relevance. Based on a notion of shared governance and institutional polyarchy (Ostrom, 2010), it is possible to discuss in-depth and using other lenses-, the constraints and effects of the processes of participation and engagement of various actors in public policy. It is about exploring the scope and limits of public action networks or epistemic communities that form around public issues (Ansell, 2012; Cefaï, 2017).

Considering this problematization, the study of social innovation ecosystems (SIEs) - their emergence, development, and effects in the "public arenas" (Cefaï, 2002) of cities - becomes a central theme in the research agenda. SIEs, in this sense, are interpreted as "network constellations" (Pel, Wittmayer, Dorland, \& Jorgensen, 2018) shaped by on the association of multiple actors, institutions, and artefacts from different sectors, which are formed by mobilization around "problematic issues" in the city's "public arenas" (Cefaï, 2002). 
Recent studies have addressed ways of reinforcing the SIEs and the capacities of the different actors that make up these networks, discussing factors that favor or inhibit SIEs (Alijani, Luna, Castro-Spila, \& Unceta, 2017; Biggeri, Testi, \& Bellucci, 2017; Pel et al., 2018). These studies point to the need to expand the understanding of ways to radiate social innovations beyond local experiments, considering them as a process, spatially negotiated and inserted into territories, and which have the objective possibility of influencing development patterns (MacCallum, Moulaert, Hillier, \& Vicari, 2009).

This article takes into account the contribution of these studies and seeks to advance in the debate, emphasizing the reality of cities in developing countries by exploring the SIE of Florianópolis, in Brazil. In the last decade, Florianópolis has gained a position nationally recognized as the 'capital of innovation,' bringing together different collectives, organizations, and institutions (whether in the private, government, or civil society) that have triggered social innovation initiatives.

Thus, this research seeks to understand the extent to which and how ordinary actors that make up the socio-technical network of the Florianópolis SIE (support organization or social innovation initiatives) identify, interpret, mobilize, and react to the city's public problems and, in so doing, coproduce social innovations. It is particularly interesting to understand the emergence, diffusion, and effects of open social innovations understood as autonomous and undetermined social dynamics of "coping with problematic situations" in the city's public arenas (Cefaï, 2017; Cefaï \& Terzi, 2012).

The leading strategy to understand these dynamics was the creation of an open digital platform, using a collaborative approach, with the participation of the subjects studied. As pointed out by Sestini (2012) and Angelidou and Psaltoglou (2017), online platforms are essential tools for collaboration, coconstruction of solutions, dissemination of knowledge, and the diffusion and exchange of experiences, allowing for a broader reach and impact of the SIE.

This text presents the theoretical and methodological approach elaborated to map and assess the Florianópolis SIE and used to co-construct the platform, as well as it shows the lessons learned during this collaborative process. The analytical-theoretical approach adopted here promotes a dialogue between recent studies on SIE (Alijani et al., 2017; Biggeri et al., 2017; European Commission, 2014; Lévesque, 2016; Pel et al., 2018; Stam, 2015) and the sociology of public problems inspired in pragmatism (Cefaï, 2002, 2014, 2017; Cefaï \& Terzi, 2012; Chateauraynaud, 2011; Chateauraynaud \& Dubaz, 2017; Dewey, 1927; Quéré \& Terzi, 2015). This dialogue emphasizes aspects that are little considered in the current debate on SIEs, such as the multiscale dynamics of social innovation, its territorial and socio-historical inscription and the connection with public problems and public arenas.

The following sections addresses the design of this theoretical-methodological approach in three complementary parts. First, discussing the literature on SIEs, highlighting the perspectives and gaps in this debate. The next section discuss the need for new theoretical and methodological approaches that can account for different trajectories and formats of the SIE. It means to highlight the consequences of SIEs in the public sphere and, regarding practical aspects, to examine the particularities that are

\footnotetext{
${ }^{1}$ The Brazilian Ministry of Science, Technology, and Innovation elected Florianópolis as the first among the ten cities with the most innovative potential in the country (Ewers, Gomes, \& Octaviano, 2015). According to a survey by the Brazilian Startup Association (ABStartups), Florianopolis is the Brazilian city with the largest number of startups per inhabitant (Agência Brasil, 2018). Florianopolis was considered by Newsweek Magazine one of the ten most dynamic cities in the world in a list that considers the presence of clean industry, knowledge and the use of cutting-edge technologies (PMF, 2019).
} 
typical of cities in developing countries. Then, the theoretical assumptions of the research and the relationship between these assumptions are presented, leading to the analytical framework used in this work. Finally, the research methodology and its different moments are explained, emphasising the lessons learned throughout the process, offering reflections and considerations for future studies and suggesting new research agendas.

\section{THE SCIENTIFIC DEBATE ON SOCIAL INNOVATION ECOSYSTEMS: PERSPECTIVES AND GAPS}

The debate about Social Innovation Ecosystems (SIEs) is recent in specialized literature and still lacks a more robust theorization. As Lévesque (2016) argues, the origin of the concept is related to studies on innovation ecosystems (IEs) developed since the 1960s, mainly in the management and economic fields. Most of these studies focus their analysis on business ecosystems (BEs) (Moore, 1993) or entrepreneurial ecosystems (EEs) (Isenberg, 2011), following a Schumpeterian tradition.

Studies on BEs represent an advance regarding the concept of innovation system (IS), as they consider that innovation dynamics can be influenced by several interconnected factors, of which cultural/institutional context and support networks (financial, human capital, infrastructure, for example) are essential components. The effectiveness of BEs is determined by how well the elements interact and respond to the demands of the broader socioeconomic system. In this sense, the analogy with ecosystems is used to highlight the plurality of actors that constitute the phenomenon, their interactions, open governance, and the epistemic communities forming these ecosystems. However, the literature on BEs, in practice, emphasizes the action of the companies, showing examples in which centralized forms of governance and competition dynamics are more frequent than collaboration (Kœnig, 2012).

Continuing this debate, studies on EEs fill some of these gaps, giving centrality to the role of the entrepreneur, the enterprises, and their relationships with the different support agents involved in their actions. Studies on EEs evolve to focus on the interrelationship among different domains in supporting entrepreneurial action (Isenberg, 2011) involving policies (providing financial support, legitimacy and a legal framework to facilitate entrepreneurship); markets (production expertise, consumers, distribution channels and others); capital and financing; human resources; entrepreneurial culture (risk acceptance, stimulating innovation); and technical support. In addition, beyond the support structure, the studies show the centrality of the agents' role (entrepreneurs).

When focusing more specifically on the theme of social innovation, the literature discussing the notion of "ecosystems" is still incipient, and it is more common to observe the use the term Social Innovation System (SIS) - as mentioned by Fulgêncio and Le Fever (2016) in a systematic review on the topic. The authors stated that SIS is a concept originated in the systems theory and has been applied to the field of innovation since the 1980s. They consider the social innovation system concept as "an inter-connection of actors and objects in developing, diffusing, and utilizing innovation targeting social issues or needs" (Fulgêncio \& Le Fever, 2016, p. 445). Both in this definition built by the authors and in the definitions they researched in the review (conducted with 15 articles identified in the Google Scholar database in the period from 2000 to 2012), the concept of SIS appears as an adaptation of the notion of Innovation System (IS) to the social field. The authors' review identified that the concept was treated based on three levels of analysis, focusing on the economic and technical dimensions of innovation: a) institutional; b) organizational; and c) societal. 
So, studies focusing on SIEs - from a particular perspective - are still scarce, as observed in searches conducted in the scientific databases in October 2016. In the ISI database, searches were made in the social sciences area from 2012 to 2016 using the term "social innovation ecosystems," which returned 19 articles. Of these, only four referred to studies on SIEs. Searching Google Scholar, using the same terms and the same period, 85 references were found, of which only eight were studies related to SIEs.

When analyzed as a whole, it is clear that most references, especially the oldest ones (Ariza-Montes \& Muniz, 2013; Cameron, 2012), following the tradition of Bloom and Dees (2008), understand the SIEs as networks of support and a set of environmental conditions that foster social entrepreneurship. The role of the social entrepreneur, in these circumstances, is crucial and the centrality of enterprises in the composition of the SIE is emphasized. There is a clear dialogue with studies on EEs, using normative (pre-established categories) and universal explanatory models, which makes little contribution in terms of understanding the dynamics and consequences of the different SIEs.

More recently, some studies have taken a broader and more sophisticated approach to analyze SIEs. These works are characterized not only by addressing the elements that favor social entrepreneurship or social enterprises but by bringing new agendas to the debate, giving rise to the understanding of other dimensions of SIEs beyond the economic or technical.

North and Longhurst (2013), Calzada, Chautón, and Di Siena (2013), and Wolfram and Frantzeskaki (2016) discuss the importance of social innovation dynamics for promoting changes in patterns of urban development, emphasizing a multiscale and multidimensional logic for the analysis of SIEs. Another set of recent studies provides a panoramic analysis of social innovation mapping initiatives, examining their scope and boundaries and paving the way for future research.

Pelka and Terstriep (2016), for example, present and analyze 17 projects mapping social innovation, pointing out advances and limits. The article shows mapping social innovation as a trend, especially in developed countries. Initiatives carrying out this kind of activity have multiplied in recent years, using different methodologies and exploring comparative analysis. These approaches enable fruitful outcomes regarding material for research. On the other hand, the authors demonstrate the existence of essential gaps to be explored. They raise the awareness that new projects on mapping have adopted their own definition of social innovation, often privileging a specific dimension, sector, or actor. In this sense, multidimensional and multiscale perspectives are little explored.

Another gap pointed out is related to the little dialogue with the target audiences involved in social innovation initiatives and the absence of interaction among the initiatives themselves. In this sense, studies often start from a normative logic and methodologies that give little room to understand the particularities of the dynamics and visions/regimes present in each of the regions/territories analyzed. Pelka and Terstriep (2016) argue that most projects focus on general and universal problems such as unemployment, demographics, and climate change, making it difficult to understand the specific demands of each territory. Finally, the authors observed that little is discussed about the consequences of these initiatives in the territories analyzed.

These same findings were confirmed in the SI Drive project that led to the Atlas of Social Innovation, coordinated by Howaldt, Kaletka, Schröder, and Zirngiebl (2018). The authors highlight the importance of further empirical studies on social innovation and SIEs, seeking to understand "its various manifestations, actors and cultural contexts, and frees the term from the narrow confines of a limited rather traditional economic orientation that is focused on the concept of social entrepreneurship" (Howaldt et al., 2018, p. 12). Based on this argument, Pel et al. (2018, p. 6) show 
the problems of positions that reduce SIEs to mere support networks for some "innovation heroes" (be they social movements, social entrepreneurs, community organizations, or others). The authors compare twenty transnational social innovation networks and advocate for a relational perspective where social innovations are "embedded, fluid, and provisional" units of analysis.

Authors exploring theoretical-analytical models for SIEs confirm these findings. As pointed out by MacCallum et al. (2009) and Calzada et al. (2013), the dynamics of social innovation are experimental and do not occur massively. They express the ability of actors to harness the development of territories. These processes are territorially negotiated and embedded, and an in-depth analysis should consider this context.

Stam (2015) and Lévesque (2016) add stating that most recent studies are based in the literature on innovation, and they import models into the social field, without considering the particularities of social innovation. The majority of these studies adopt a structural-functionalist perspective, offering models that focus on the role of "supplier," performed by support institutions and highlight the existence of some key actors in the SIEs. These models are, consequently, little concerned with the "demands," i.e., the dynamics of social innovation and their impact on public problems or social needs, which are the reasons that connect the different actors to the SIE. In this sense, authors draw attention to the need for less normative frameworks, looking for other solutions that overcome the limitations ready-made or tautological models trying to explain social innovation and its effects.

From the dialogue with this debate, its achievements and its shortcomings, were then conceived the theoretical and analytical assumptions and the methodological approach used in this study to conduct the cartography and analysis of SIE of Florianopolis. These elements are presented below.

\section{A PRAGMATIST LOOK AT SOCIAL INNOVATION ECOSYSTEMS: THEORETICAL BACKGROUND AND ANALYTICAL ASSUMPTIONS}

The many socio-environmental problems currently experienced have their most direct effects in the cities, which are privileged places of complex relationships - in time and space - among economic, social, technological, and ecological dynamics that accelerate or hinder patterns of sustainable development (Wolfram \& Frantzeskaki, 2016). However, developing research on these relationships (interconnected, intersectoral, nonlinear, complex. and undetermined) poses a challenge. Even the most recent studies that seek to look at SIEs have gaps and do not capture the dynamics of social change, focusing on more structural and normative analysis.

In this sense, Chateauraynaud and Dubaz (2017) point out that a pragmatist and "adaptive" perspective may help to think of SIE as an opportunity to building possible futures, from the analysis of the long trajectories based on actions, practices, and experiences led by the actors themselves. These trajectories are formed by processes of confrontation between the actors' endeavors when facing a variety of problems. As advocated by Ostrom (2010), it is a matter of considering a polycentric and multiscale approach that confers centrality to learning by experience in facing public problems, which are indeed global but lived locally.

This pragmatist reading entails an understanding of the social innovation dynamics that emerge in the city. Social innovation can be interpreted as a process of social change that requires "democratic experimentation" (Ansell, 2012; Bohman, 2004), or the mobilization and engagement of different 
collectives around the consequences produced by the city's public problems. Therefore, social innovations are not considered as the result of isolated actions, but as result of agencies/associations (Latour, 2012) of different actors and actants, from different sectors (government, market, and civil society), who have the possibility to co-invent new solutions to address their challenges (Andion et al., 2017).

This can result in new objects, processes, practices, or changes in the social relations and cultural patterns of a territory. Therefore, social innovation is understood as a practice in the making - involving processes, products, and consequences (effects beyond the affected people) - which result from situated public actions. Thus, it can be constituted as a vector for the construction of new trajectories and "possible worlds" by the different "publics" (Dewey, 1927) that constitute the city's public arenas.

Cefaï (2002) and Chateauraynaud (2011), based in John Dewey work, define the public arenas as 'living-labs of politics', composed of different territorial scales and by individual, organizational, and institutional actors that can, over time, commit to a collective effort to identify and manage public problems. It is in the public arenas that the processes of "democratic experimentation" occur. According to Ansell (2012), the experiments that occur in the real world are the real experiments and the idea of the laboratory is only a variation of this.

The notion of experimentation is central for Dewey's democratic theory - and for his entire work. For the author, there is no social reality outside experience. In other words, reality cannot be defined as something complete and harmonious, a background separated from what we are as humankind. Reality is produced from the experience of the world, from the interaction between living creatures and the environment:

Reality must be conceived as experience. Each experience, because it is unfinished, requires others to verify and complete them. Reality is then partly experimental: only the accumulation of experiences, the "accumulation of details" enables to gradually learn more about the reality of the world around us. Following an experimental logic, the reality is always in "transformation toward," in perpetual change and production (Truc, 2005, pp. 3-4 our translation).

From this perspective, performing cartography and observing the experiences of SIEs is a (always unfinished) way to understand how - in these public arenas (or living laboratories) - dynamics of "democratic experimentation" or "public inquiry" are produced, or, how the different publics engage, interpret, discuss, publicize, and promote solutions to the public problems they face. Dewey's "public inquiry" (1938) occurs when active audiences or "communities of experience" are formed. When co-constructing knowledge, these publics promote collective intelligence and inter-objectivation (Zask, 2004). A public inquiry, therefore, has a collective nature and is co-produced. In public inquiry dynamics researchers and social actors interact and a plurality of views, activities, knowledge, and interests are taken into account. In this way, various forms of situated knowledge can be co-constructed (Smith, Around, Fessoli, Thomas, \& Abrol, 2012).

It is a "design experiment," in which the experimenter assumes that the object will interact with the entire scenario in which the experimentation is conducted (Ansell, 2012). Thus "democratic experimentation" means considering that "publics" are experimenters, subjects of "public inquiry," 
without needing the intervention of an exterior 'authority'.

As Quéré and Terzi (2015) explain, the analysis of activities related to the emergence of problems and their publics offers a privileged way to understand the political forms as they are being built and their dynamics of change. In this process, the situations of proof and the criticism produced are essential, as they may constitute turning points or ruptures in the trajectories of public problems. Chateauraynaud and Dubaz (2017) argue that each dossier has a critical gradient that must be considered. Thus, the processes of a public inquiry (when they occur) are not linear and may be recursive and even stagnant, passing through indifference, managerial or technical criticism, or a more radical, transformative critique, that may produce cynicism or paralysis.

These authors argue, therefore, that the analysis of public arenas must consider the ballistics of social transformation (Chateauraynaud, 2011), or how a cause or public problem is re-signified and takes on new configurations over time, leading to mobilization, engagement, or institutionalization. It is important to consider multiple scales of analysis, the temporality of public problems, and their relation with the territory (milieux).

Based on this background and previous studies (Andion et al., 2017; Moraes \& Andion, 2018; Gonsalves \& Andion, 2019), a pragmatist perspective on SIEs, presuppose a particular analytical approach that allows entering these diverse "public arenas," identifying the actors, their interactions, retracing this reticular mesh and observing the experiences in situ. The pragmatist approach adopted here makes it possible to see SIEs in another way, based on four interrelated assumptions that underlie the analytical-methodological framework, presented below.

\section{- Assumption 1: Considers that SIEs are embedded in long trajectories of configuring public} problems in specific territories (positioned in time and space).

In this sense, considering the socio-historical, institutional, and territorial scenario of SIEs is fundamental, keeping in mind the demands or public problems of the territory, given that they are collectively and historically built (macro scale).

- Assumption 2: Interprets the dynamics of social innovation as processes of change (incremental or broader) that produce consequences and emerge from the associations between multiple human and non-human actors (such as individuals, collectives, organizations, institutions, technologies, methodologies) in public arenas.

Therefore, SIEs are formed from interconnections that subscribe to various public arenas. Identifying the main actors, their interactions, practices, and consequences is an essential step (mesoscale).

- Assumption 3: Examines the dynamics of social innovation as embedded in "fields of experience" (Cefaï, 2014) in which different audiences engage in solving problematic situations and in the process of public inquiry. 
Thus, the analysis of the SIEs must go beyond a macrostructural or reticular perspective, to monitor the situations of the public's "democratic experimentations." This involves closely observing the processes of justification and criticism produced by the actors and the outcomes obtained. Such processes are related to how "publics" deal with problematic situations, such as identifying, interpreting, making criticisms, co-constructing knowledge, or proposing solutions.

- Assumption 4: To analyze the scope and consequences of social innovation dynamics, it is important to reconnect them to the broader processes of social change, considering the interconnexion between macro, meso, and micro dimensions of social reality, keeping a longitudinal perspective.

Therefore, observing the actors' practices and their connections over time becomes central, as the practices reveal the engagement of different audiences in facing certain problems in different arenas, bringing out the production of critical capacity (their arguments and their justifications). This view can enable a better understanding of the dynamics from which the different actors reconfigure (or not) the horizons of the possibilities in the city's different public arenas or fields of cause.

\section{ANALYTICAL APPROACH AND METHODOLOGY OF THE STUDY ON THE FLORIANÓPOLIS SOCIAL INNOVATION ECOSYSTEM}

Consistently with the assumptions outlined above, the main strategy of the research portrayed in this article was the creation and implementation of a collaborative digital platform (Sestini, 2012) called the Observatory of Social Innovation of Florianopolis (OBISF) (www.observafloripa.com.br) (Figure 1). OBISF is a virtual, open, collaborative space that promotes learning through experimentation, involving various actors of the city's SIE (whether support organizations or social innovation initiatives).

The implementation of OBISF occurred through: a) a process of co-creation between the university researchers and actors that form the SIE in Florianópolis; b) connection between teaching, research, and community service (extension); c) interdisciplinary dialogue between the undergraduate and graduate programs of public and business administration of the Santa Catarina State University. The implementation of the initiative within the university is possible due to the partnership of two research centers. The project occurs under the leadership of two research-professors and involves the undergraduate and graduate (master and doctoral students).

Some aspects were central in the composition of the analytical and methodological framework of this project: a) a multiscale and multidisciplinary perspective, understanding SIEs as a "nexus" of practices (Frega, 2016), involving actors from multiple spheres (government, business, and civil society) and various segments or causes (education, health, environment, children and adolescents, among others); b) a longitudinal and socio-spatial analysis, through geo-referencing and longitudinal monitoring of different "democratic experiments" in the city of Florianópolis, recognized as national center of social innovations; and c) a collaborative approach that promotes experiential learning, creating spaces in each stage for actors to build their own explanations and theories, valuing and stimulating processes of public inquiry. 


\section{FIGURE $1 \quad$ PLATFORM'S HOME PAGE}

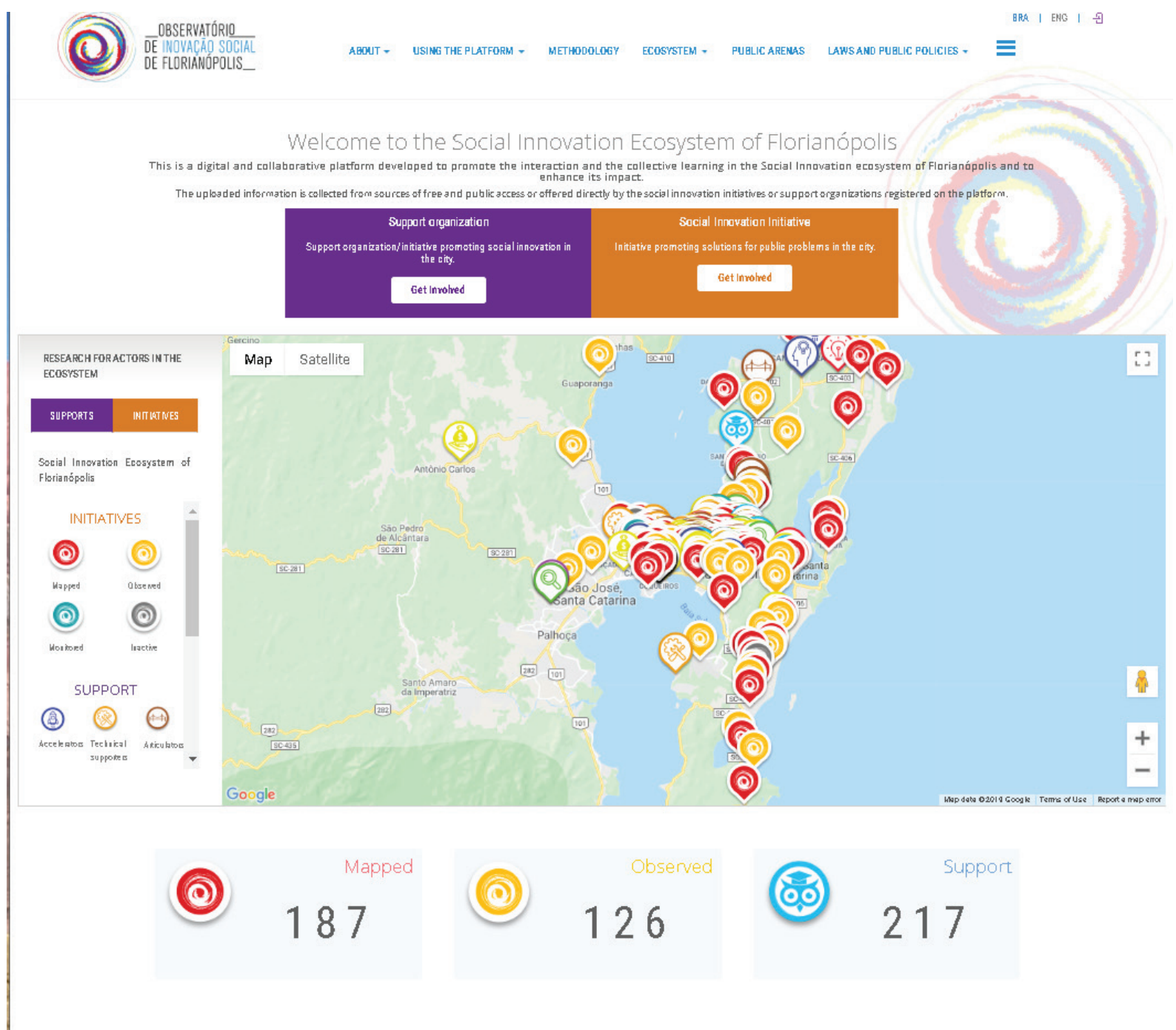

Source: Observatory of Social Innovation of Florianopolis (2019).

Given these preliminary aspects, the project's analytical framework and methodological way are structured in four main moments, summarized in Figure 2 and briefly explained below. It is noteworthy that these moments did not occur linearly, because the research involved a long process of "inter-objectivation" (Zask, 2004), resulting in several comings and goings between research and experiences in the real world, between researchers, platform developers, and actors of the SIE. Those were interactions between ideas and phenomena, theory and practice, taking into account a plurality of visions, interests, and aspirations, at the moment of designing both the research methodology and the online platform. 


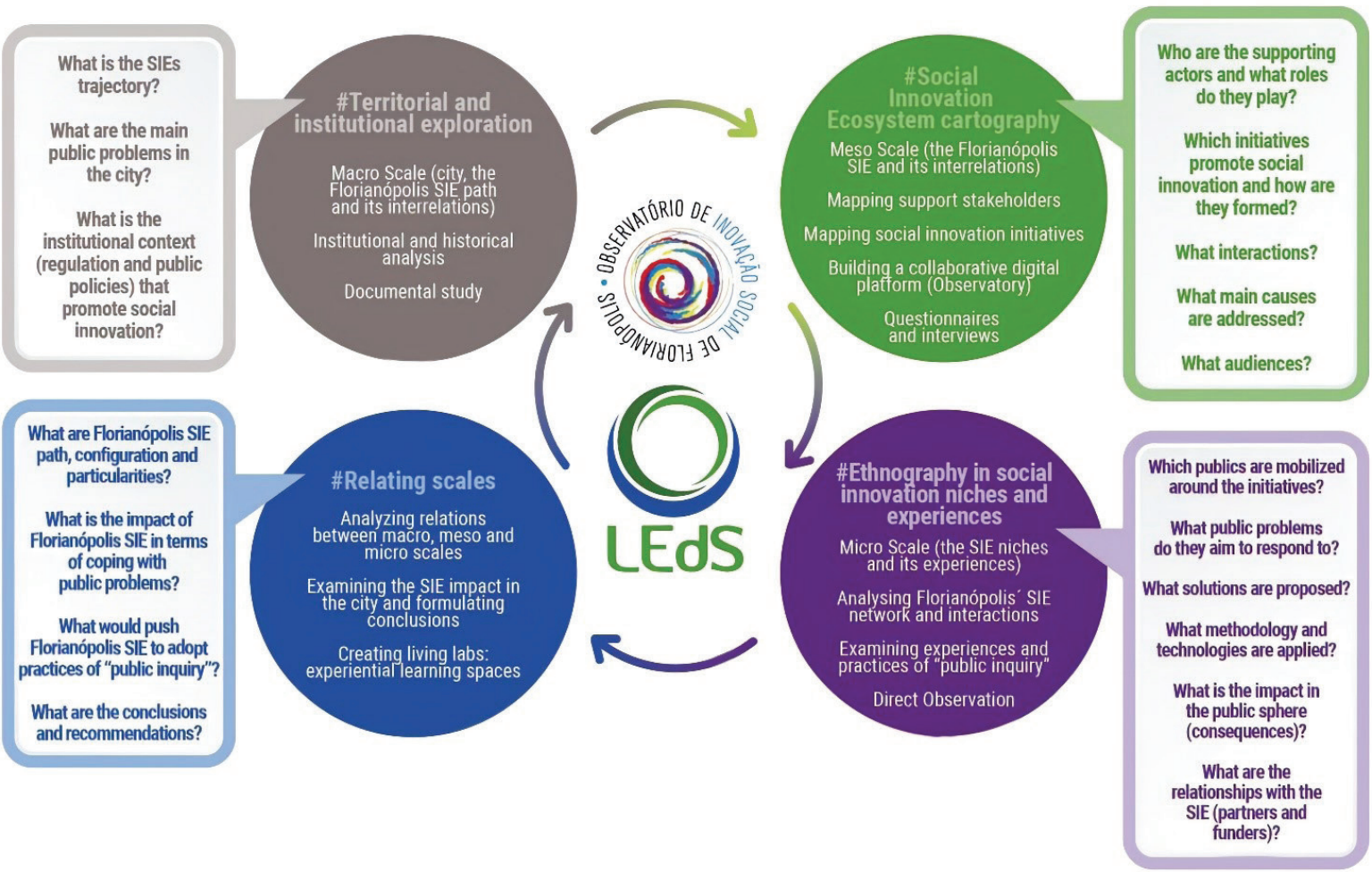

Source: Observatory of Social Innovation of Florianópolis (2019).

\subsection{Territorial and institutional exploration}

The unit of analysis used at this moment was the city of Florianópolis, and involved two complementary steps, which will be briefly explored: a) an analysis of the SIE's trajectory and its socio-territorial immersion, with emphasis on the description and analysis of the main public problems of the city; and (b) an examination of the institutional environment of the SIE composed of laws, policies, and programs for fostering social innovation at the municipal, state, and federal levels.

\subsubsection{Analysis of the trajectory and territorial immersion of the SIE}

This step involved the reconstitution of the historical trajectory of the SIE by collecting documentary data and interviews with key participating informants, which allowed the construction of a narrative about the (re)configuration of the SIE in the city over time, based on the actors' perspective. The purpose of this analysis was to visualize the different publics and "communities of experience" (Zask, 2004) that form the SIE, highlighting their contribution to its history and constitution, underlining the plurality of actors and forms of engagement that compose the network.

The studies and interpretations that these different collectives produce about the city's public problems constitute a second aspect analyzed in the SIE trajectory. The data were extracted from 
various reports prepared and published by the SIE's actors and were chosen because they represent the public debate about the city's present and future challenges. Among the documents consulted, the following stand out: a) Relatório Florianópolis 1950-2050 (Florianópolis Report), prepared by the Florianópolis Urban Planning Institute (IPUF) (Campanário, 2008); b) Relatório Desafios de Florianópolis (Florianópolis Challenges Report), proposed by Movimento Floripa Te Quero Bem (2012); c) Plano de Ação Florianópolis Sustentável (Florianópolis Sustainable Action Plan) prepared by the Iniciativa Cidades Emergentes e Sustentáveis (Emerging and Sustainable Cities Initiative) (ICESS Brasil, 2015); d) Relatório Sinais Vitais (2015 and 2016) (Vital Signs Report), prepared by the Community Foundation for Greater Florianópolis (ICOM, 2015 and 2016), through mobilization of different actors and experts; e) Relatório Dinâmico (Dynamic Report) (Portal dos Objetivos do Milênio, 2016); and f) Plano Diretor de Florianópolis (Florianópolis Master Plan) (PMF, 2017).

These reports were examined and synthesized, selecting the main public problems identified by the Florianópolis SIE actors and disclosing them in the online platform ${ }^{2}$. So, the platform allows establishing correlations between the social innovation initiatives and the problems identified, visualizing the networks of the public arenas around the problems of the city, and the responses offered to them. New public problems, which are not necessarily published in reports, are also identified and publicized on the platform.

\subsubsection{Analysis of the institutional environment of the SIE in the city}

As discussed above, the dynamics of social innovation are influenced by a number of interconnected factors, including institutional devices that can stimulate or inhibit the dynamics of SIEs. Thus, an exploratory mapping of laws and public policies to support social innovation in the city was carried out, based on a documentary analysis at the federal, state, and municipal levels. This information is available on the platform. ${ }^{3}$

The documents were accessed on the official websites that provide this information, using the search terms "innovation" and "social innovation." This survey showed that there is still little dissemination and incentive in terms of programs, regulations and policies to support social innovation in the state of Santa Catarina and in Florianópolis.

With this preliminary information, it was possible to provide an overview of the macro scale, considering the socio-historical, territorial, and institutional dimensions of the phenomenon, to relate them to the other scales studied.

\subsection{Cartography of the SIE in Florianópolis}

The cartography of the Florianópolis SIE was initially performed by exploratory research, started in April 2016, using the snowball technique. Initially, socially recognized actors that supported social innovation in the city were interviewed and indicated other actors to form the map. For this stage a

\footnotetext{
${ }^{2}$ The network of public arenas and the public problems with which they engage can be found at http://www.observafloripa.com.br/ispage//publicProblems. To acess the information it is necessary to be logged in the platform.

${ }^{3}$ See at http://www.observafloripa.com.br/is-page//publicPolicyOfInnovation. To acess the information it is necessary to be logged in the platform.
} 
questionnaire was elaborated, later incorporated on the platform, containing the following information fields of the support organizations: a) contact data; b) role in supporting social innovation, activities performed and target audience; c) supported social innovation initiatives and other partner support organizations.

This exploratory survey mapped the contact data and the role played by 115 support organizations, whose information was initially used to build the platform. During this phase, 10 categories of support organizations were identified: a) training centers; b) promotion of social entrepreneurship; c) research and extension centers; d) funders; e) technical supporters; f) articulators and bridging actors; g) spaces for communication, dialogue, and reflection; h) incubators; i) accelerators; and j) certifiers.

In October 2016, questionnaires were sent to the 35 support actors who were nominated at least two times in the initial phase. They each received the online form to provide the registration information and indicate at least three social innovation initiatives they supported. By February 2017, when the platform was created, 17 questionnaires were returned indicating 59 social innovation initiatives, which were mapped. In this phase, the team working in the project collected public information about these initiatives, data such as a) contact data; b) type of initiative (legal status); c) cause in which it operates; and d) target audience. From the information collected, it was possible to place the initiatives in a geo-referenced map and start mapping the network ${ }^{4}$ of the interrelations between the support organizations and the social innovation initiatives they work with.

Based on this mapping and during the design and testing period of the platform (from February to September 2017), it was possible to identify some of the main actor-network of the city's SIE. Dialogues were set up with 11 actors, who became partners of the platform and supported its planning and implementation, involving representatives from: a) the city and state government; b) civil society organizations that have an important articulating role; c) companies that act as promoters of social innovation and social entrepreneurship with the market and the government; and d) other research groups that deal with the theme nationally and internationally.

The dialogue and connections of these different actors that make up the city's SIE and the launch of the platform in September 2017 allowed considerable expansion and deepening of the cartography of the ecosystem. Partners and the registered actors were involved in the effort to collect and complement the information. With the platform launched, actors could go online and add their information autonomously. Currently (August 2019), there are 227 support organizations and 307 social innovation initiatives registered on the platform that respond to the public problems in the city. Among the social innovation initiatives, 196 were mapped and 111 observed (4 of which are systematically monitored for longer-term research) ${ }^{5}$. The initiatives observed have more detailed

\footnotetext{
${ }^{4}$ The network can be visualized by accessing: http://www.observafloripa.com.br/is-page//ecosystemNetwork. To acess the information it is necessary to be logged in the platform.

${ }^{5}$ In June 2017, just before launching the platform, there were 124 support organizations and 81 social innovation initiatives mapped. Only 19 of them were monitored at that time. These initial numbers help to observe the expansion of almost $100 \%$ in support organizations mapped and a 300\% increase in the number of social innovation initiatives registered. Also, the number of initiatives monitored increased fivefold in two years of research.
} 
information with full completion of the online form, containing, in addition to contact details, the type of initiative and its cause, information about the public problem it addresses, the solutions that it puts into practice, whether it uses specific technologies or methodologies, and information on the incidence on the public arena in which it operates, as well as listing its supporters and other partner social innovation initiatives.

The number of initiatives observed could be increased thanks to the involvement of undergraduate students who, during the semester, as part of the courses attended, conduct on-site visits and followup on social innovation initiatives mapped in the city. This activity made it possible to broaden the involvement of the academic community with research and also with the city's SIE, as well as to connect research with teaching and extension.

\subsection{Following public arenas and social innovation practices}

To follow the "fields of experience" of social innovation in Florianópolis, systematic studies are being conducted by post-graduate students, examining initiatives in which there is evidence of social innovation dynamics in the city's public arenas. Based on mapping and previous studies, some experiences in public arenas stood out and are being closely monitored through ethnographic studies: a) the city's network for guaranteeing children's and adolescents' rights; b) the municipal forum for public policies; c) the municipal solid waste treatment network; d) the connection between food security and urban agriculture; and e) the mobilization to defend women's rights.

The intention is to observe the "fields of experience" of the analyzed public arenas, rather than only examining isolated initiatives. Together with the OBISF platform, the Laboratory of Education for Sustainability and Social Innovation (LEDS) was implemented. LEDS is a "living laboratory" (Veeckman, Schuurman, Leminen, \& Westerlund, 2013) that promotes different university extension activities inside the institution and in the community. The proposal is to monitor and facilitate processes of public inquiry within different arenas. From the monitored experiences and activities such as projects, events, and workshops, together with the actors and based on their demands, LEDS and OBISF intend to consolidate as spaces of collaboration for the co-production of knowledge in the interaction between the knowledge produced in the university and the knowledge generated in the SIE.

\subsection{Interrelating Scales}

This long-term study aims to promote a multiscale and longitudinal understanding of the Florianópolis SIE relating its historical, territorial, and institutional dimensions (macro scale), with the analysis of its network of associations, forms of cooperation and interaction (mesoscale), including practices (micro-scale), and outcomes (consequences). It is about monitoring, in loco, how the SIE performs at the interface between the already established institutions and the creative potential of the different actors in the ecosystem (Frega, 2016). In this sense, the final goal is to foster experiences of problematization, publicization, exploration, and collective learning dealing with public problems and democratic experimentation, based on monitoring and supporting the mapped social innovation dynamics. 
It is a matter of "problematizing" the Florianópolis SIE, collaboratively co-constructing the phenomenon under study. This process of "experimentation" is intended to disclose the reality of the SIE, offering visibility to work done by ordinary actors who co-produce social innovation in their daily lives, emphasizing their achievements toward solving public problems. This process has been built not only by "researchers" (students and professors) but by everyone involved in this "community of experience" (Zask, 2004).

\section{FINAL CONSIDERATIONS}

This article presented the theoretical and methodological approach that has guided the study of the SIE of Florianópolis, Brazil. The starting point was the analysis of the most recent studies on this theme, as well as the gaps and perspectives for future research. Secondly, the article explained the assumptions used to conceive the analytical framework outlined in Figure 2. This analytical approach considers that government, civil society, and business actors have an objective possibility of promoting social innovation and foster dynamics that support or inhibit the construction of solutions to the city's public problems in various public arenas. These complex dynamics are interconnected and immersed in different institutional/territorial scales (macro), the interrelations between the collectives (meso) and the experiences lived by the actors themselves (micro), forming a network that performs social innovation in the city.

To put this analytical approach into practice, the article explains how a collaborative platform to mapping the SIE came about, identifying the support actors and social innovation initiatives, tracing their interrelationships by operating a living laboratory, a space that promotes collective learning about the SIE, and focusing on the dialogue between actors and researchers. The collaborative construction of the platform and the living laboratory led to the materialization of a theoretical and methodological approach distinguished from the epistemological traditions of conceiving social innovation based on a technological, economic, or managerial perspective. This classical perspective emphasizes social entrepreneurs as the main leaders responsible for the development of new ideas, products, and services, to satisfy social needs. This study contributes to understanding that the experiences of social innovation emerge from collective actions produced in this reticular web permeated by conflicts, and that, at the same time, produce collaboration and participation, that could be vectors of transformation in the city's development trajectories.

This implies a notion of SIE that goes beyond the idea of structure and system, generating new practices and dynamics that (re)connect social, economic, and cultural aspects to actors' traditions and collaborative capacity. Such processes, in the long run, can allow social transformations in the public spaces of the city.

Studying SIE by understanding public arenas as fields of collective action and emphasizing the practices of actors - considering their relationship with the history and the territory -, is not an easy task and requires analytical and methodological choices. These choices, while bringing advances to the understanding of the phenomenon, also put limits to the scope of the study, focuses on the reality of Florianópolis, which is a city within a particular context in Brazil. The outcomes obtained here, therefore, do not necessarily apply to other cities or regions of Brazil and other countries. The 
RAP | Social innovation ecosystems, sustainability, and democratic experimentation: a study in Florianopolis, Brazi

theoretical-analytical approach presented here, however, may inspire and offer subsidies to other experiences. It this sense, an advance of this research agenda is to work comparing the dynamics of the SIE of Florianópolis with other cities in Brazil, Latin America, and North countries, exploring similarities and differences, and strengthening the studies on SIE.

Finally, in addition to understanding the configuration of the SIE, the network, forms of interactions among actors, and the consequences of these interactions in the public arenas, this work focuses on strengthening and disseminating practices of public inquiry in the city, contributing to reinforce the dynamics of democratic experimentation, and promoting change towards more sustainable development styles. In this sense, it is hoped that this study can contribute to co-create useful and contextualized knowledge that makes sense, empower and can be appropriate by actors that form the city's SI. 


\section{REFERENCES}

Agência Brasil. (2018). Florianópolis é o destaque no mapa das startups. Retrieved from https://dcomercio. com.br/categoria/tecnologia/florianopolis-e-odestaque-no-mapa-das-startups

Alijani S., Luna, A., Castro-Spila, J., \& Unceta, A. (2017). Building capabilities through social innovation: implications for the economy and society. Finance and economy for society: integrating sustainability. Critical Studies on Corporate Responsibility, Governance and Sustainability, 11, 293-313.

Andion, C., Ronconi, L., Moraes, R. L., Gonsalves, A. K. R., \& Serafim, L. B. D. (2017). Sociedade civil e inovação social na esfera pública: uma perspectiva pragmatista. Revista de Administração Pública, 51(3), 369-387.

Angelidou, M., \& Psaltoglou, A. (2017). An empirical investigation of social innovation initiatives for sustainable urban development. Sustainable Cities and Society, 33, 113-125.

Ansell, C. (2012). What is democratic experiment? Contemporary Pragmatism, 9(2), 159-180.

Ariza-Montes, A. J., \& Muniz, N. M. (2013). Virtual ecosystems in social business incubation. Journal of Electronic Commerce in Organizations, 11(3), 27-45.

Armitage, D. R., Plummer, R., Berkes, F., Arthur, R. I., Charles, A. T., Davidson-Hunt, I. J. ... Wollenberg, E. K. (2009). Adaptive co-management for socialecological complexity. Frontiers in Ecology and the Environment, 7(2), 95-102.

Biggeri, M., Testi, E., \& Bellucci, M. (2017). Enabling ecosystems for social enterprises and social innovation: a capability approach perspective. Journal of Human Development and Capabilities, 18(2), 299-306.

Bloom, P. N., \& Dees, G. (2008). Cultivate your ecosystem. Stanford Social Innovation Review, 6(1), 45-53.

Bohman, J. (2004). Realizing deliberative democracy as a mode of inquiry: pragmatism, social facts and normative theory. Journal of Speculative Philosophy, 18(1), 23-43.

Calzada, I., Chautón, A., \& Di Siena, D. (2013). Macro meso micro: systemic territory framework from the perspective of social innovation. Retrieved from https://www.researchgate.net/ publication/314529414

Cameron, H. (2012). Social entrepreneurs in the social innovation ecosystem. In A. Nicholls, \& A. Murdock (Eds.), Social innovation. Blurring boundaries to reconfigure markets (pp. 199-220). London, England: Palgrave Macmillan.

Campanário, P. (2007). Florianópolis: dinâmica demográfica e projeção da população por sexo, grupos etários, distritos e bairros (19502050). Retrieved from http://www.pmf.sc.gov. br/arquivos/arquivos/pdf/06_05_2016_ 10.57.51.165f6d5987d5575003562ec5bbdd5850.pdf

Cefaï, D. (2002). Qu'est-ce qu'une arène publique? Quelques pistes pour une approche pragmatiste. In D. Cefaï, \& I. Joseph (Orgs.), L’héritage du pragmatisme. Conflits d'urbanité et épreuves de civisme (pp. 51-82). Paris, France: La Tour d'Aigues.

Cefaï, D. (2014). Investigar los problemas públicos con más y allá de Joseph Gusfield. In J. Gusfield. La cultura de los problemas públicos (pp. 11-54). Buenos Aires, Argentina: Siglo XXI.

Cefaï, D. (2017). Públicos, problemas públicos, arenas públicas. Novos Estudos CEBRAP, 36(1), 187-213.

Cefaï, D., \& Terzi, C. (2012). L'expérience des problèmes publics. Paris, France: Perspectives Pragmatistes.

Chateauraynaud, F. (2011). Argumenter dans un champ de forces. Essai de balistique sociologique. Paris, France: Petra.

Chateauraynaud, F., \& Dubaz, J. (2017). Aux bords de l'irreversible. Sociologie pragmatique des transformations. Paris, France: Petra.

Cidades Emergentes e Sustentáveis. (2015). Plano de Ação Florianópolis Sustentável. Retrieved from http://www.ibam.org.br/media/arquivos/estudos/ plano_de_acao_florianopolis_sustentavel_bid_ caixa.pdf

Dewey, J. (1927). The public and its problems. Chicago, IL: Swallow Press.

Dewey, J. (1938). Lógica. Teoría de la investigación. Pánuco, México: Fondo de Cultura Económica. 
European Commission. (2014). Building the social innovation ecosystem. A deliverable of the project: "The theoretical, empirical and policy foundations for building social innovation in Europe" (TEPSIE) (7th Framework Programme). Brussels, Belgium: Author.

Ewers, J., Gomes, M., \& Octaviano, C. (2015, 05 setembro). MCTI e Revista Inovação mapeiam as dez cidades mais inovadoras do país. Revista Eletrônica de P,D\&I. Retrieved from https://www.inovacao. unicamp.br/especial/mcti-e-revista-inovacaomapeiam-as-dez-cidades-mais-inovadoras-do-pais/

Fischer, F., \& Gottweis, H. (2013). The argumentative turn in public policy revisited: twenty years later. Critical Policy Studies, 7(4), 425-433.

Frega, R. (2016). Quést-ce qu'une pratique? In F. Chateuraynaud, \& Y. Cohen (Orgs.), Histoires pragmatiques. Raisons pratiques (pp. 321-347). Paris, France: Éd. EHESS.

Fulgêncio, H., \& Le Fever, H. (2016). What is the social innovation system? A state-of-the-art review. International Journal of Business Innovation and Research, 10(2-3), 434-452.

Gonsalves, A. K. R, \& Andion, C. Ação pública e inovação social: uma análise do sistema de garantia de direitos da criança e do adolescente de Florianópolis-SC. Revista Organizações \& Sociedade, 26(89), 221-248.

Howaldt, J., Kaletka, C., Schröder, A., \& Zirngiebl, M. (Eds.). (2018). Atlas of social innovation: new practices for a better future. Dortmund, Germany: TU Dortmund University.

Howlett, M., Ramesh, M., \& Perl, A. (2013). Política pública: seus ciclos e subsistemas - uma abordagem integral. Rio de Janeiro, RJ: Elsevier.

Instituto Comunitário Grande Florianópolis. (2015). Sinais Vitais Florianópolis: Checkup 2015. (pp. 1-63). Florianópolis, SC: Author. Retrieved from http:// comunicacao.icomfloripa.org.br/sinais-vitaisflorianopolis-2015

Instituto Comunitário Grande Florianópolis. (2016). Sinais Vitais Crianças e Adolescentes Florianópolis 2016. (pp. 1-83). Florianópolis, SC: Author. Retrieved from http://comunicacao.icomfloripa.org. br/sinais-vitais-2016-crianca-adolescente
Isenberg, D. (2011, 11 maio). The entrepreneurship ecosystem strategy as a new paradigm for economic policy: principles for cultivating entrepreneurship. In Proceedings of the Conference in Institute of International European Affairs. Dublin, Ireland.

Konig, G. (2012). Le concept d’écosystème d'affaires revisité.M@n@gement,15(2),209-224.

Latour, B. (2012). Reagregando o social: uma introdução à teoria do ator-rede. Salvador, BA: Ed. UFBA.

Lévesque, B. (2009). Economia plural e desenvolvimento territorial na perspectiva do desenvolvimento sustentável: elementos teóricos de sociologia econômica e de socioeconomia. Política \& Sociedade, 8(14), 107-144.

Lévesque, B. (2016). Économie sociale et solidaire et entrepreneuriat social: vers quels nouveaux écosystèmes? Revue Interventions Économiques, 54.

MacCallum, D., Moulaert, F., Hillier, J., \& Vicari, S. (2009). Social innovation and territorial development. Farnham, England: Ashgate.

McPhearson, T., Andersson, E., Elmqvist, T., \& Frantzeskaki, N. (2015). Resilience of and through urban ecosystem services. Ecosystem Services, 12(Special), 152-156.

Moraes, R. L \& Andion, C. (2018) Civil Society and Social Innovation in Public Arenas in Brazil: Trajectory and Experience of the Movement Against Electoral Corruption (MCCE). Voluntas, 29, 801-818.

Moore, J. (1993). F. Predators and prey: a new ecology of competition. Harvard Business Review, 71(3), 75-86.

Movimento Floripa Te Quero Bem. (2012). Desafios de Florianópolis. Subsídios para Elaboração do Plano de Metas. Retrieved from http://www.icomfloripa. org.br/icom/wp-content/uploads/2014/05/FTQBparte-1.pdf

North, P., \& Longhurst, N. (2013). Grassroots localisation? The scalar potential of and limits of the 'transition' approach to climate change and resource constraint. Urban Studies, 50(7), 1423-1438.

Observatório de Inovação Social de Florianópolis. (2019). Conheça o Ecossistema de Inovação 
Social de Florianópolis. Retrieved from www. observafloripa.com.br

Osborne, S. P. (2006). The new public governance? Public Management Review, 8(3), 377-387.

Ostrom, E. (2010). Beyond markets and states: polycentric governance of complex economic system. American Economic Review, 100, 641-672.

Pel, B., Wittmayer, J., Dorland, J., \& Jorgensen, M. S. (2018). Unpacking the social innovation ecosystem: a typology of empowering network constellations. In Annals of the 10o International Social Innovation Research Conference (ISIRC). Heidelberg, Germany.

Pelka, B., \& Terstriep, J. (2016). Mapping social innovation maps. The state of research practice across Europe. European Public \& Social Innovation Review, 1(1), 3-16.

Portal dos Objetivos do Milênio (2016). Relatórios dinâmicos, indicadores de monitoramento. Retrieved from www.portalodm.com.br

Prefeitura Municipal de Florianópolis - PMF. (2016). Plano Diretor de Florianópolis. Retrieved from http:// www.pmf.sc.gov.br/sites/planodiretor/

Prefeitura Municipal de Florianópolis - PMF. (2019). "Ilha do Silício": Rede de Inovação Florianópolis faz da capital um polo de tecnologia. Retrieved from https://g1.globo. $\mathrm{com} / \mathrm{sc} / \mathrm{santa}$-catarina/especial-publicitario/ prefeitura-municipal-de-florianopolis/florianopolisuma-cidade-para-todos/noticia/2019/07/04/ ilha-do-silicio-rede-de-inovacao-florianopolis-fazda-capital-um-polo-de-tecnologia.ghtml

Quéré, L., \& Terzi, C. (2015). Pour une sociologie pragmatiste de l'expérience publique. SociologieS, Dossiers, (Pragmatisme et sciences sociales: explorations, enquêtes, expérimentations). Retrieved from http://journals.openedition.org/ sociologies/4949
Sestini, F. (2012). Collective awareness platforms: engines for sustainability and ethics. IEEE Technology and Society Magazine, 31(4), 54-62.

Shields, P. M. (2008). Rediscovering the taproot: is classical pragmatism the route to renew public administration? Public Administration Review, 68(2), 205-221.

Smith, A., Around, E., Fessoli, M., Thomas, H., \& Abrol, D. (2012, June). Grassroots innovations for sustainable development: some enduring dilemmas. In Proceedings of the Global Research Forum on Sustainable Consumption and Production Workshop. Rio de Janeiro, RJ.

Stam, E. (2015). Entrepreneurial ecosystems and regional policy: a sympathetic critique. European Planning Studies, 23(9), 1759-1769.

Truc, G. (2005). Introduction par Gérôme Truc. In J. Dewey, La réalité comme expérience. Retrieved from https://journals.openedition.org/ traces/204\#tocto1n 1

Veeckman, C., Schuurman, D., Leminen, S., \& Westerlund, M. (2013). Linking living lab characteristics and their outcomes: towards a conceptual framework. Technology Innovation Management Review, 3(11), 6-15.

Vieira, P. F., Cazella, A., Cerdan, C., \& Carrière, J. P. (2010). Desenvolvimento territorial sustentável no Brasil. Subsídios para uma política de fomento. Florianópolis, SC: APED.

Wolfram, M., \& Frantzeskaki, N. (2016). Cities and systemic change for sustainability: prevailing epistemologies and an emerging research agenda, Sustainability, 8(2), 1-18.

Zask, J. (2004). L'enquête sociale comme interobjectivation. In B. Karsenti, \& L. Queré (Dirs.), La croyance et l'enquête: aux sources du pragmatisme (pp. 141-163). Paris, France: Éd. EHESS. 


\section{Carolina Andion}

https://orcid.org/0000-0003-4723-3437

$\mathrm{PhD}$ in Interdisciplinary Human Sciences; Associate Professor in the Center of Administration and Socioeconomic Sciences (ESAG) at Santa Catarina State University (UDESC); Leader of the Center for Social Innovation in the Public Sphere (NISP). E-mail: andion.esag@gmail.com

\section{Graziela Dias Alperstedt}

https://orcid.org/0000-0003-0144-0406

$\mathrm{PhD}$ in Production and Systems Engineering; Associate Professor in the Center of Administration and Socioeconomic Sciences (ESAG) at Santa Catarina State University (UDESC); Leader of the Research Group Strategos - Dimensions and Process in Organizations. E-mail: gradial@gmail.com

\section{Júlia Furlanetto Graeff}

https://orcid.org/0000-0002-3121-8032

$\mathrm{PhD}$ in Administration; Researcher of the Center on Social Innovation in the Public Sphere (NISP) in the Center of Administration and Socioeconomic Sciences (ESAG) at Santa Catarina State University (UDESC). E-mail: jufgraeff@gmail.com 